\title{
The Design of Application for Accelerating Funding Proposal Selection Using the Object-Oriented Hypermedia Design Method
}

\author{
Rezki Kurniati ${ }^{*}$, Sri Mawarni ${ }^{2}$
}

\author{
${ }^{1}$ Politeknik Negeri Begkalis, Indonesia \\ ${ }^{2}$ Politeknik Negeri Bengkalis, Indonesia \\ *Corresponding Author: Email: rezkikurniati@gmail.com
}

\begin{abstract}
The Savings and Loans Unit (USP) is an economic business that provides loans in the form of money for village community business activities for individuals or groups considered productive. The process of borrowing funds is carried out by submitting a loan proposal with terms predetermined by the USP. The purpose of this research is to make an application design for accelerated loan proposals using the Object-Oriented Hypermedia Design Method (OOHDM), which can be implemented in the recommendation system for funding loan proposal selection. OOHDM is used in the design of web applications that are oriented towards building large hypermedia. This research produces a web-based application design whose access rights can be used by the USP as an admin as well as a lending decision-maker and a fund user/borrower submitting a loan proposal.
\end{abstract}

Keywords: Object-oriented hypermedia design method, savings, and loan units, application design

\section{INTRODUCTION}

The Savings and Loans Unit (USP) is an economic business that provides loans in the form of money for village community business activities, both for individuals and groups that are considered productive. The process of borrowing funds is carried out starting with submitting a loan proposal with the conditions determined by the USP. The selection of proposals using the criteria set by the USP.

Selection of proposals with certain criteria can use the application by ranking based on the highest value of the selected proposals, it can record the track record of borrowers (track records), both those with problems and those that are smooth in payment [1]. Web-based selection application with large hypermedia requires a method in its design, one of the methods that can be used is OOHDM. OOHDM is an object-oriented software approach method with an application model used to build large hypermedia applications. In a web application that uses the concept of the OOHDM method consisting of a conceptual model, a navigation model, an interface model, and implementation, so that analysts and developers can concentrate on one concept at a time, these four concepts are carried out separately to get a more modular and reusable design [2].

This study makes an application design for accelerating the selection of loan proposals using the OOHDM method which can be implemented in the USP loan selection recommendation system which includes data storage of users, system users carried out by the manager (admin) and the user (borrower).

Previous research [3], used the OOHDM method in its design to be implemented in school academic information systems. This method was successfully applied in system implementation by developing the OOHDM design concept into four stages, namely: requirement gathering (a method based on user activity), conceptual design (in the form of output, namely class, and the relationship of the system), navigation design and abstract interface design.

Other researchers who use the OOHDM method in web design are the school alumni web [4], and the laboratory web [5], who also apply four stages in their design. This method has also been successfully 
implemented on the website by adding database design and modification to integrate the interface with the database as well as adjusting system interaction patterns with users.

Research related to proposal selection, conducted by [6], aims to assist managers in selecting loan proposals. Two assessors carried out the proposal selection. Proposals are sorted from proposals that have the highest value, decision making also goes through deliberation to reach a consensus from the manager. The result of this research is a recommendation system based on ranking.

Another relevant study was conducted [7], aimed at building a decision support system to measure the severity of depression, anxiety, and stress disorders. This disorder has a total of 42 items/symptoms known as DASS-42. In this study, a Group Decision Support System (GDSS) model was built which allows psychologists to collaborate in providing preferences regarding the priority of disorders that will occur if certain items/symptoms are known according to DASS42. Preference is given in an ordered vectors format. The result is to accommodate the preferences of decisionmakers in giving weight to influence. Anxiety disorders and stress disorders have very similar symptoms so that for several items/symptoms in DASS-42 there are quite significant differences. Research on decision support that has been carried out uses one object for one problem.

Taking into account the review of previous studies, this study makes an application design for accelerating the selection of loan proposals using OOHDM which can be implemented in a decision support system that has a database for users, and the user has a login to see his history.

\section{METHODS}

In designing a loan proposal selection application design, the methodology used is as follows [8], [9]:

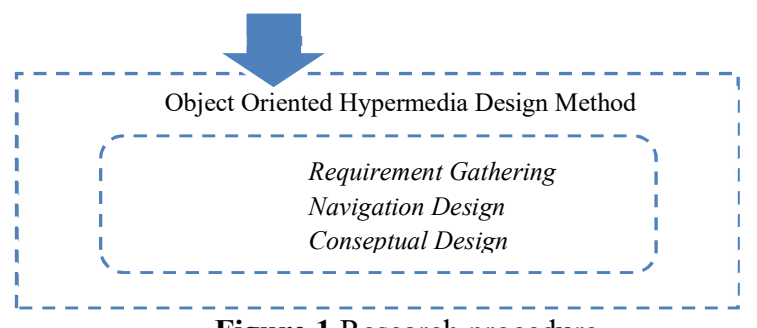

Figure 1 Research procedure

At the analysis stage, problem identification is carried out through a survey. From the survey results, data needed for the selection of loan proposals are data of potential beneficiaries, proposal data, collateral data, USP employee data.
In designing a loan proposal selection application design, the methodology used is web engineering design using OOHDM with stages requirement gathering, navigation design, conceptual design [10], [11]. The design that has been made is poured in the form of making a website for selecting loan proposals for funds

\subsection{Stages of Requirement Gathering}

At this stage, an analysis of the functional requirements of the application will be designed and then proceed to the design stage. The data needed at this stage is information related to the loan fund proposal selection system and the parties involved in selecting proposals by the loan fund manager. This stage consists of the role and task identification, scenario specification, use case specifications, and user interaction diagram specification (UID).

\subsubsection{Role and Task Identification}

The proposal selection application consists of Administration (admin) people who have full rights to manage the application, the Chair of USP is the person in charge of all management activities, here the Head of USP can see the results of the selection and reports. Beneficiaries are users who have an account to upload proposals and view various information related to proposals.

Role and task identification of each actor is presented in table 1 [12].

Table 1. Role and task actor

\begin{tabular}{|l|ll|}
\hline \multicolumn{1}{|c|}{ Actor } & \multicolumn{2}{c|}{ Task } \\
\hline Admin & $\begin{array}{l}\text { 1. } \\
\text { 2. }\end{array}$ & $\begin{array}{l}\text { Admin manages application user accounts } \\
\text { Admin manages the requirements for } \\
\text { submitting a loan proposal }\end{array}$ \\
3. $\begin{array}{l}\text { Admin manages information about the } \\
\text { results of proposal selection }\end{array}$ \\
\hline $\begin{array}{l}\text { Chairman } \\
\text { of the USP }\end{array}$ & $\begin{array}{l}\text { 1. } \\
\text { The USP Chairperson sees the results of } \\
\text { the selection }\end{array}$ \\
\hline Utilizers & $\begin{array}{l}\text { The Chairperson looks at the user data } \\
\text { 2. }\end{array}$ & $\begin{array}{l}\text { The user registers to get an account } \\
\text { The user uploads the proposal } \\
\text { requirements to the web. } \\
\text { The user does manage personal data } \\
\text { Beneficiaries get information on the } \\
\text { results of selecting proposals }\end{array}$ \\
\hline
\end{tabular}

\subsubsection{Scenario Specification}

It is a narrative explanation of how the application is used to complete the tasks of each actor, this scenario is presented in Table 2 . 
Table 2. Scenario specification

\begin{tabular}{|c|c|}
\hline Actor & Scenario \\
\hline Admin & $\begin{array}{l}\text { 1. Manage User Accounts } \\
\text { 2. Admin to add, delete user accounts. } \\
\text { 3. Manage Terms } \\
\text { 4. Admins make additions, gratuities, and } \\
\text { change the terms of submission of } \\
\text { proposals by applicable rules. } \\
\text { 5. Manage information on the results of } \\
\text { selecting proposals } \\
\text { 6. On the information menu of the proposal } \\
\text { selection, the admin adds information } \\
\text { according to the results of the selection. }\end{array}$ \\
\hline $\begin{array}{l}\text { Chairman } \\
\text { of the USP }\end{array}$ & $\begin{array}{l}\text { 1. See the results of the selection } \\
\text { 2. The Chairperson of the USP can see the } \\
\text { results of adding information on the } \\
\text { results of the selection made by the } \\
\text { Admin. } \\
\text { 3. Viewing user data } \\
\text { 4. The USP Chair looks at the list of } \\
\text { beneficiaries registered in the database. }\end{array}$ \\
\hline Utilizers & $\begin{array}{l}\text { 1. The user registers to get an account } \\
\text { 2. The User registers by filling in the } \\
\text { account name, password } \\
\text { 3. The user uploads the proposal } \\
\text { requirements to the web. } \\
\text { 4. After logging into the application the } \\
\text { user can submit a proposal by uploading } \\
\text { the conditions that have been } \\
\text { determined. } \\
\text { The user does manage personal data } \\
\text { 6. Information on user data is managed by } \\
\text { the user himself. The user can fill in the } \\
\text { data according to the conditions of the } \\
\text { problem } \\
\text { Beneficiaries get information on the } \\
\text { results of selecting proposals } \\
\text { Information on the results of selecting } \\
\text { proposals can be seen in each user } \\
\text { account }\end{array}$ \\
\hline
\end{tabular}

It is a grouping of scenarios in functional units in UML, the use-case specification in this study consists of use case managing user accounts presented in table 3, Registration use cases are presented in table 4, Use case selection of proposals is presented in table 5, Use cases Information on the results of proposal selection is presented in Table 6, User interaction specification diagram (UID) which is presented in Figure 1.

Table 3. Use case specification manage user accounts

\begin{tabular}{|l|}
\hline Use-case: Manage User Accounts \\
\hline Scenario: Admin (1) \\
\hline Roles/ Actor: Admin \\
\hline Description: \\
1. The system application display on the Admin account \\
displays user data that can be managed by the admin \\
2. Admin can overwrite and delete users. \\
\hline
\end{tabular}

Table 4. Use case registration

\begin{tabular}{l} 
Use-case: Benefits of registering to get an account \\
Scenario: Admin (2) \\
\hline Roles / Actor: Admin \\
\hline Description: \\
1. Select the registration menu. The system displays \\
the registration form. \\
2. Fill in the user name and password. Then choose \\
the list.
\end{tabular}

3. Registration successfully displays the home page.

Table 5. Selection of proposal use cases

\begin{tabular}{|l|}
\hline Use case: Results of proposal selection \\
\hline Scenarios: Admin (3) / Chair of USP (1) / User (4) \\
\hline Roles: Admin / Chair of USP / Beneficiary \\
\hline Description: \\
1. The beneficiary proposes a loan \\
2. The user enters the document in the application \\
3. The system will determine the eligibility of loan \\
applications based on the completeness of documents \\
and past loan payments arrears. \\
5. Thin will input the selection results of loan \\
whether it is accepted or not. \\
6. The USP Chair can see loan applications, loan \\
selection results, and user loan documents.
\end{tabular}

Table 6. Use case information on the results of proposal selection

\begin{tabular}{|l|}
\hline Use-case: Information on the results of proposal selection \\
\hline Scenario : Admin (3) / Head USP (1) / User (4) \\
\hline Roles : Admin / Head USP / User \\
\hline Description: \\
1. On the menu in the account, each role displays \\
information about the proposal selection. \\
2. Information on the results inputted by the admin \\
\hline
\end{tabular}

\subsubsection{User interaction diagram specification (UID)}

UID is used to link the design between the designer and the user. The following picture is the UID of the user account registration [13] (figure 2).

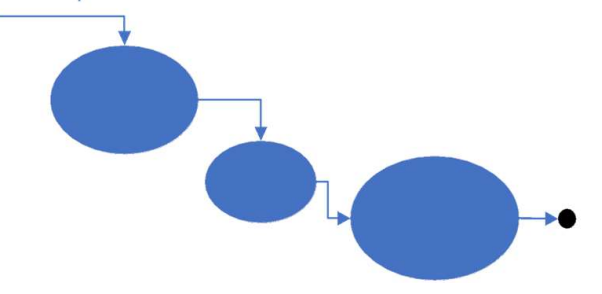

Figure 2. User account registration UID 
Admin will input user data and grant user access rights. There are two levels of access rights to users namely admin is a user who has full rights to the management of the application and ordinary users are users who can only view information. After the user gets a username and password, then the user can log in to the application.

The user submits a loan to the application, then the user will input documents or requirements for submitting a proposal. The system will determine the eligibility of a loan application based on the completeness of documents and past loan payments arrears. admin prints a list of user names whose proposals will continue to survey potential beneficiaries.

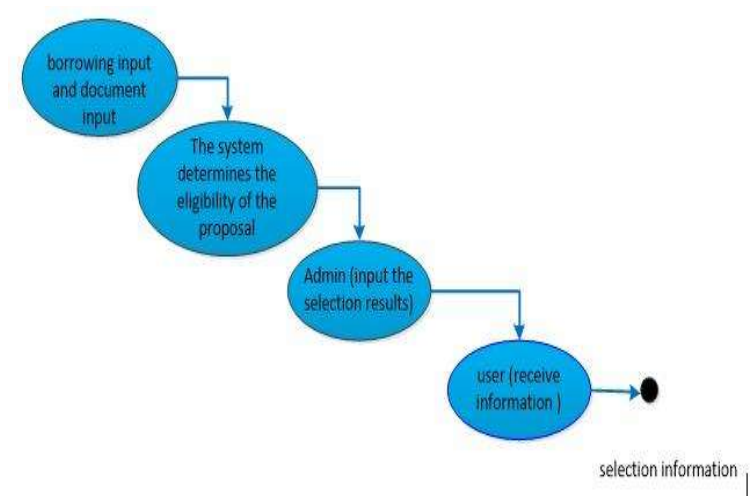

Figure 3. UID for proposal selection

After the survey the next step is village deliberation. after there are results, the admin enters the results of the proposal selection in the application, each role can see the information on the selection results of the proposal.

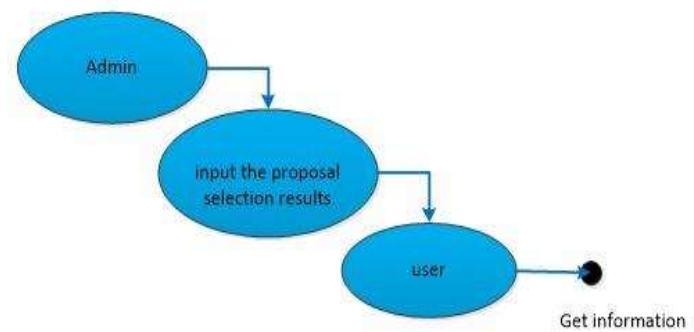

Figure 4. UID of proposal selection results

\subsection{Conceptual Design}

The conceptual design describes the relationships between tables in a database. The design table includes user tables, user tables, Agama tables, loan tables, document tables, and collateral tables. The relationship between tables is stated in the form of an entityrelationship diagram [14], [15].

Each table has a primary key that characterizes each table. The main key is symbolized by an underlined oval attribute. every related table has the same attributes.

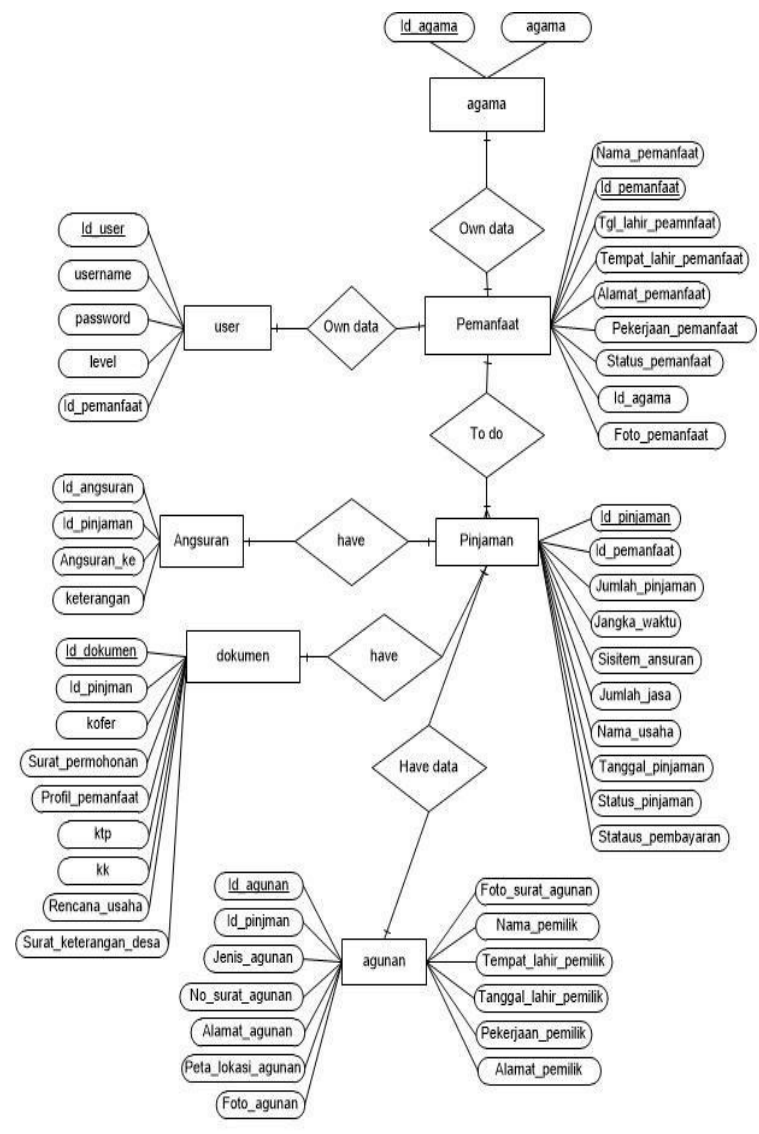

Figure 5. ERD application for proposal selection

\subsection{Navigation Design}

This stage consists of designing a navigation system that is a class diagram and a navigation structure diagram. In this system, the application has a master data menu which includes the religion sub-menu, USP manager, head of USP, BPD, village assistants. The User menu includes managing user accounts. The user data menu includes the user data management sub-menu, profile view, and loan data. on loan, data can make additional loans. enter requirements and information about the status of submitting a proposal. The document print menu has submenus for installment plan forms, purchase plans, and inventory lists as shown in figure 6. 


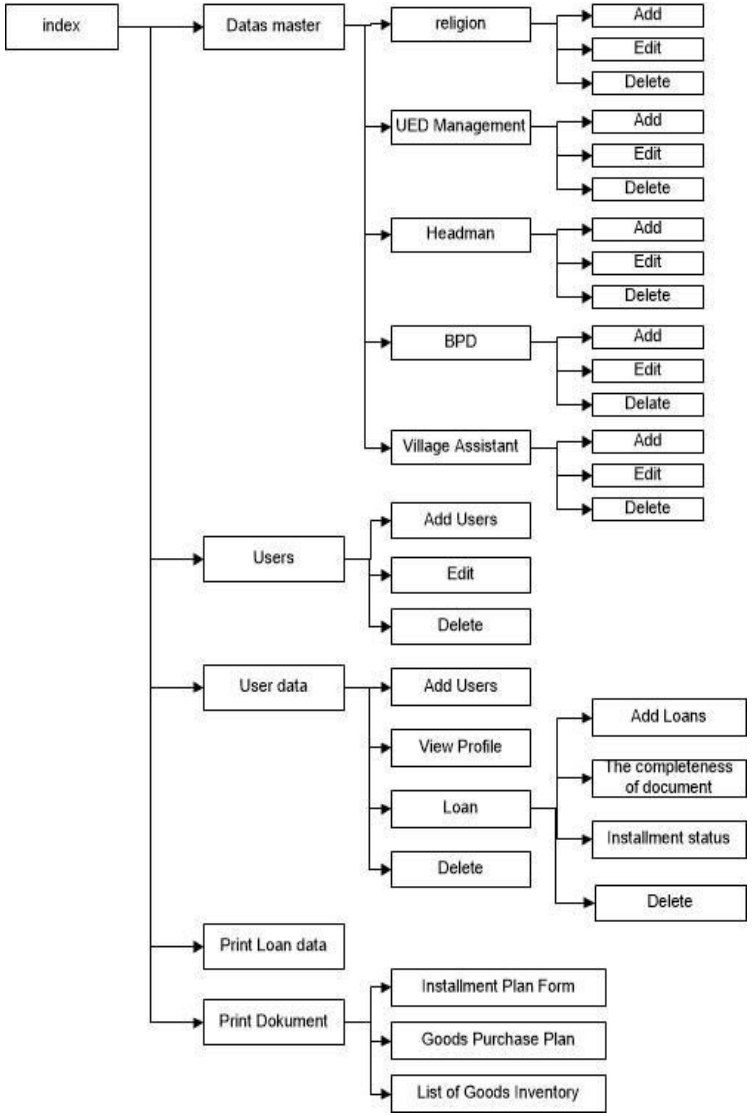

Figure 6. Application navigation structure

\section{RESULTS AND DISCUSSION}

The design using OOHDM is expected to help the users to access information about the proposal submission and assist the admin in selecting the proposal for the first stage.

\subsection{Prototype Application}

Following are the results of the prototype selection of loan fund proposals, which are presented in Figure 7

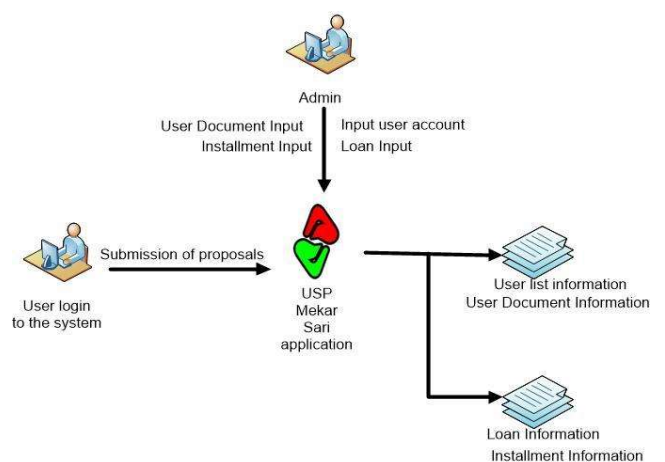

Figure 7. Results of the prototype design of fund proposal selection Applications

\subsection{User Account Management View}

Account management is carried out by the admin, the admin can add, delete user account data.

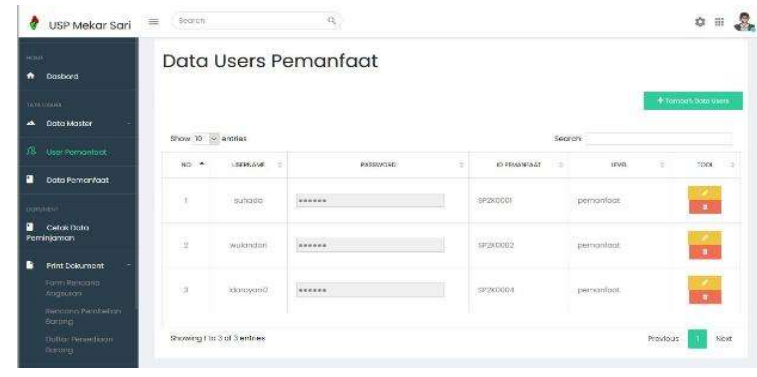

Figure 8. User account management

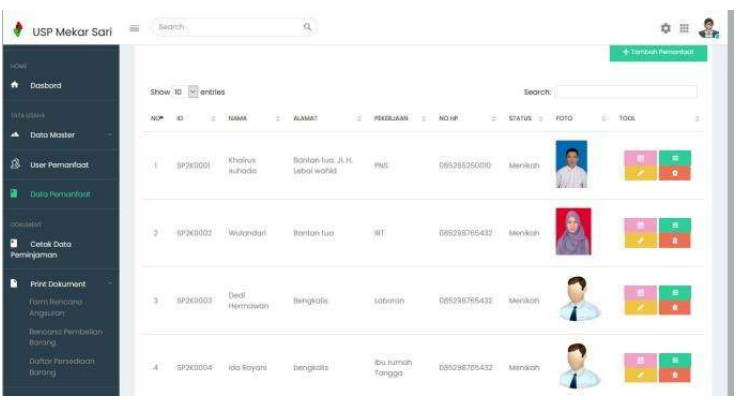

Figure 9. List of user accounts

\subsection{User Registration View}

Data of beneficiaries who make loans are recorded in the add user data menu.

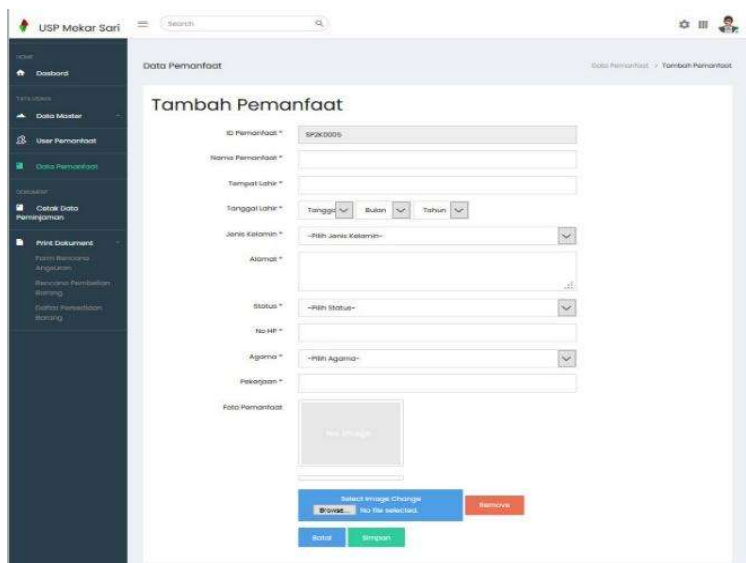

Figure 10. User registration

\subsection{Proposal Selection View}

After recording the data, the user can proceed to submit a proposal. The user brings the complete submission in the form of a soft file. All data must be filled in according to their needs. The system manages 
recommendation proposals to be continued or not. This can be seen in Figure 11.

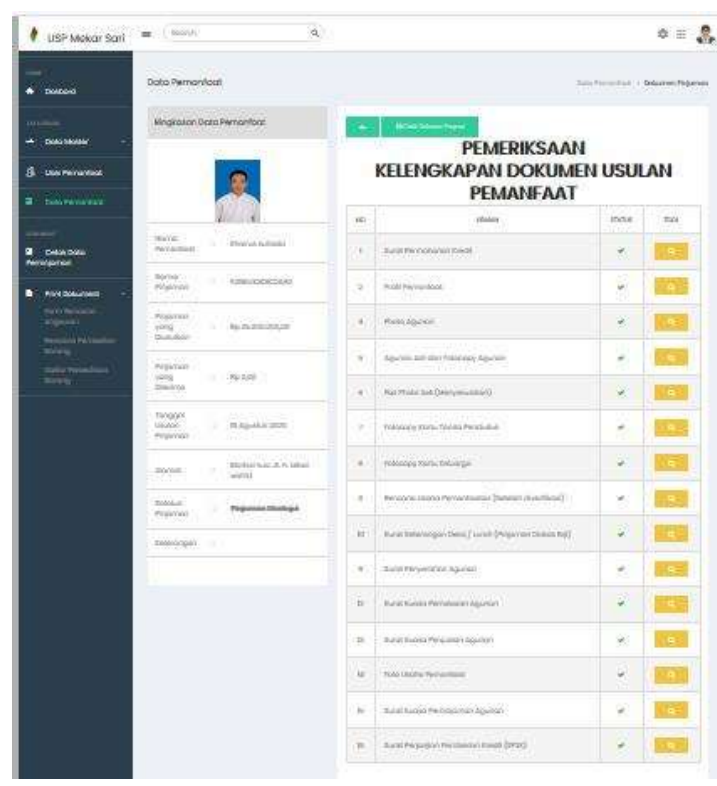

Figure 11. Proposal selection management

Funding proposal approval information is presented in Figure 12.

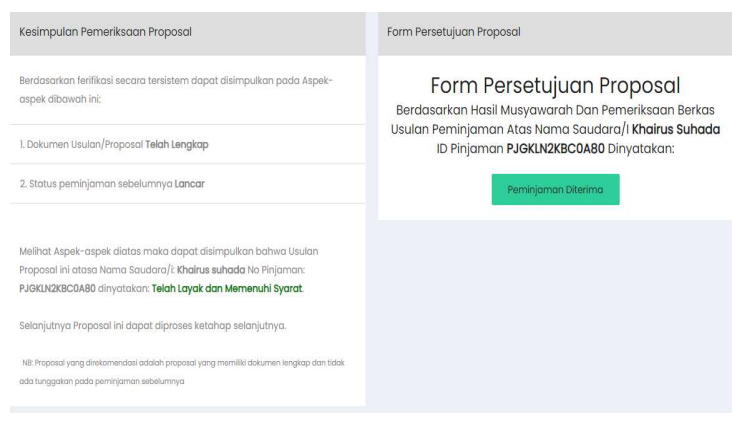

Figure 12. Approval of the proposal

\subsection{View Of Information On The Results Of Proposal Selection}

View of recommended and non-recommended proposal information can be seen in loan data (Figure 13).

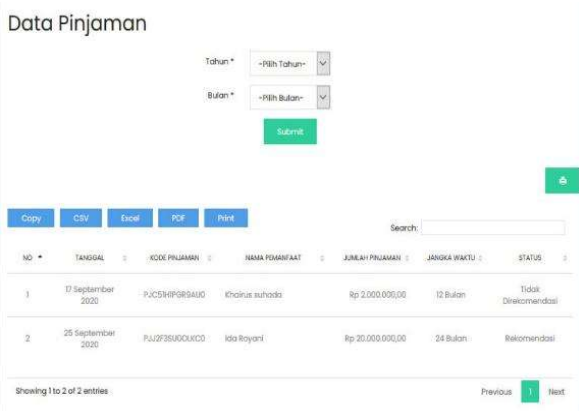

Figure 13. Information on the results of proposal selection

\section{CONCLUSIONS}

The results of the design using the OOHDM method that has been made can be implemented in making webbased systems by adding database designs as needed and codifying the design into a program to integrate the database with the interface and adjust the interaction pattern of the system with the user.

The design has been implemented in a web-based fund lending proposal selection system that has three access rights, input features in the form of data on borrowers of funds, and output features in the form of printable proposals and information on whether to accept or reject proposals, with a process in the system in the form of recommendation on the feasibility of a loan proposal.

\section{REFERENCES}

[1] Ratnawati dan Kurniati, "Penerapan Aplikasi Penyeleksian Propossal Peminjaman Dana UEDSP”, J_Dinamika Jurnal Pengabdian Masyarakat, Vol 4, No 1, 2019.

[2] D. Schwabe, R. M Guimaraes, \& G. Rossi, "Cohesive Design of Personalized Web Application”, Prosiding IEEE Internet Computing, 2002.

[3] Asmura, Afriyudi, M. Ari, "Implementasi Object Oriented Hypermedia Design Method Pada Sistem Informasi Akademik SMK Madyatama", ShaP SITI, Fakultas Ilmu Komputer, 2017.

[4] F. Dimas, R. Eko, I. Andri, "Perancangan Web Alumni Di Sekolah Menengah Kejuruan Negeri 3 Garut”, Jurnal Algoritma Sekolah Tinggi Teknologi Garut, Vol 12, No. 2, 2015.

[5] Y. Rini. U. Siti, N. Triyana, "Website Laboratorium PT. Sucofindo (Persero) Cabang Palembang Menggunakan Object Oriented Hypermedia Design Method", Jurnal Sistem Informasi STMIK PalCom Tech Palembang, 2018

[6] R. Kurniati, B. Suroso, Farikhin, "Sistem Pendukung Keputusan Penyeleksian Proposal Dana Menggunakan Metode AHP D-Numbers", Jurnal Sistem Informasi Bisnis, Vol 5, No. 12015.

[7] S. Kusumadewi and H.Wahyuningsih, "Model Sistem Pendukung Keputusan Kelompok Untuk Penilaian Gangguan Depresi, Kecemasan Dan Stress Berdasarkan Dass-42", Jurnal Teknologi Informasi dan IlmuKomputer, 7(2) 2020219 - 228.

[8] B.O. Lubis, "Penerapan Global Extreme Programming Pada Sistem Informasi Workshop, 
Seminar Dan Pelatihan Di Lembaga Edukasi”, Jurnal Informatika, 3(2) 2016 234-246.

[9] K. Beck, Extreme Programming Explained: Embrace Change, 2000

[10] J. M. Rios, and N. P. Souto, "Comparison of development methodologies in web applications", Information and Sotware Technology, 1192020 106-238.

DOI:

https://doi.org/10.1016/j.infsof.2019.106238

[11] D. Schwabe, G. Rossi, S. Barbosa, Systematic hypermedia application design with OOHDM, in Proceedings of the the seventh ACM conference on Hypertext. $1996 \quad 116-128, \quad$ DOI: https://doi.org/10.1145/234828.234840

[12] A. Dennis, B. H. Wixom, and D. Tegarden, System Analis \& Design An Object-Oriented Approach With UML, 5th Edition, 2015
[13] D. Krainer, D. E. Strockl, J. Oberzaucher, Use Case Focused User-Interaction Diagram: A Communication Tool within AAL Projects, in Proceedings of the 10th International Conference on PErvasive Technologies Related to Assistive Environments. Pages 193-196, 2017, DOI: https://doi.org/10.1145/3056540.3064944

[14] H. K. Al-Masree, "Extracting Entity Relationship Diagram (ERD) From Relational Database Schema", International Journal of Database Theory and Application, 8(3) 2015 15-26.

[15] N. E. Cagiltay, G. Tokdemir, O. kilic, and D. Topalli, "Performing and analyzing non-formal inspections of entity relationship diagram (ERD)", Journal of Systems and Software, 86(8) 20132184 2195 ,

DOI: 